\title{
Controlling Multi-input Converters to Act as Electric Energy Router
}

\author{
Israel MACIAS, David NAVARRO, Domingo CORTÉS
}

National Polytechnic Institute ESIME Culhuacan Coyoacán, D.F. 04430 México

macias.israel@hotmail.com, david.navarro.d@gmail.com,domingo.cortes@gmail.com

\begin{abstract}
It is undeniable that the energy consumption will continue to grow and the negative impact of using fossil fuels to produce it will favor the use of alternative energies. There has been an intensive research to develop clean energies from some decades now. As a result electric energy can now be generated using photovoltaic cells, wind power, fuel cells among other clean sources. Each source has advantages and disadvantages, hence, it is generally accepted that a combination of them is the best. Power electronics specialists have started to develop schemes to allow sources of different characteristics to cooperate to power a load. The device that achieve this goal has been called "energy router" by some researchers. In this work, it is shown that common multi-input power converter can function as energy routers if they are properly controlled. A control algorithm is proposed for these converters.
\end{abstract}

Keywords: Power router, Multi-input DC converters, energy transfer, hybrid systems.

\section{Introduction}

It is expected that in 2050 the world population will rise to 9 billion from its current level of 7 billion. At the same time it is projected that the world economy will grow almost four-fold, causing an increase of energy and natural resources demand [13]. There are various measures today that are being implemented to reduce the fossil energies and electric energy trying to assure a continuous and sustainable energy input for the future, and reaching the world $\mathrm{CO} 2$ emission reduction goals in 2050 to avoid a climatic chaos.

It is expected that the electric energy demand will grow $85 \%$ between 2009 and 2035 to meet the $\mathrm{CO} 2$ emission goals at least $44 \%$ of this energy will must to be generated from renewable sources. Renewable energies can be integrated in all kind of electric systems, from huge interconnected networks to small autonomous systems or buildings.

Some of the problems presented by renewable energies come from the fact that they depend on changing and uncertain environmental conditions, the load variability and perturbations present in the distribution network when they are interconnected to it (see $[7,19])$. One solution to maintain a constant energy supply are the Hybrid Energy Systems, that can combine one or more renewable energy sources with traditional storing systems that can also be interconnected with the electric energy infrastructure.
The goal of an Hybrid Energy System is to supply the demanded energy using a renewable source, even when, by itself, it's not capable of sustaining the demand. This hybrid system stores energy when the renewable source exceeds its demand, and when the demand grows it takes energy from here. If the storage system is at full capacity, and the demand is less than this, there's the possibility of pumping the excess into the distribution network. It can also take some energy from the distribution network when the hybrid system is not enough to satisfy the demand. Other realizable function is to integrate and interconnect various renewable sources, like photovoltaic or biomass production, for example $[9,12,15]$.

The interconnection of different renewable energy sources in the Hybrid Energy Systems, is a complex subject, since voltage levels can vary widely $[9,12,15]$. For example, the interconnection of an eolian generator and a photovoltaic one, taking into account multiple climatic conditions, such as a sunny day with no wind, or a cloudy day with a lot of wind and very little luminosity. So a device which allow to modify the energy proportion supplied by each source is required to take advantage from the renewable energies. So, to improve the usage of renewable energies, it is necessary to have a device capable of manipulating the power from every source, working cooperatively, and not one that just maintains a constant voltage or current. Such a device has been called energy router $[17,22]$. 
The first ideas to develop energy routers came from the so called Duindam-Stramingioli energy router. This is a mechanical device that allows several mechanical power sources to cooperate to move a body. Based on these ideas a topology of power converter to transfer energy between several devices has been proposed recently. However, till now there are not practical examples of electronic energy routers that allow several sources to feed a load cooperatively.

Ideally, an energy router should have the capacity to decide the energy percentage from every source in relation to the energy produced, cost and demand. In [17] Sánchez et al present a subsystem called Dynamic Energy Router that dynamically controls the energy flux from every source with a parameter. They show the concept using a circuit with 2 super capacitors and prove that the energy transfer exists from one super capacitor to another with a parameter they denominate $\alpha$.

Although this device transfers the energy from one point to another, it just allows the connection of two elements and the transfer of energy between them. In practice is common to find systems that require the connection of generating and consuming elements with very different dynamics. A topology that can be used as an energy router and allows to interconnect at least two different power sources is difficult to find. The topologies proposed by [17] allows to perform the energy routing, but can not connect two sources to feed a load. An improvement to this topology is presented in [22], proving that is possible to maintain the routing capability interconnecting a battery and two supercapacitors by two different topologies. The experimental results presented demonstrate the routing capability, but to implement these topologies for fuel cell applications an extensive research should be developed.

In recent years derived from DC-DC converters, multi-input converters have been developed, allowing to feed a load by at least two different voltage DC sources [1, 4, 5, 18]. Also to feed an AC load with different sources the matrix converters have been developed [3]. Multi-input converters have been used in different applications such as hybrid vehicles. For example in $[25,26]$ multi-input converters allow to interconnect different sources to achieve a desired voltage in a DC bus. On hybrid vehicles applications, a fuel cell, a battery and super-capacitors are connected to supply the required energy to the vehicle. Although the sources supply the needed energy to the vehicle, there is no policy to achieve an efficient energy usage.

Other examples to interconnect renewable energies by multi-input converters are presented in $[21,23,27]$, in these schemes the main goal is also to regulate a DC bus. Even when these solutions allow the interconnection of two sources working cooperatively the energy is not used efficiently. Most cases it is stored in batteries or sent to the electrical network. From the previous references it can be observed that control of multi-input converters has focused in regulating the load voltage $[4,5,16]$, regardless of the optimal way of using the energy.

In this paper using the equilibrium analysis it is shown that the multi-input buck and multiinput boost converters are able to function as energy routers if they are properly controlled. Furthermore a control algorithm for each both multi-input converters are proposed.

In Section 2 our view of the requirements for a circuit to be called an energy router is precised. Based on this understanding, in Section 3 a way to enable the multi-input buck converter to function as an energy router is presented. In Subsection 3.1 its model is obtained. Using an equilibrium analysis, in Subsection 3.2 it is shown that this converter could be made to work as an energy router. Then in Subsection 3.3 a control to actually make this converter to function as an energy router is presented. Simulations results of the control algorithm proposed is presented in 3.4. In Section 4 it is shown that the multi-input boost converter can also be enable to function as an energy router. Finally in Section 5 some conclusions are made.

\section{The Energy Router Control Problem}

An energy router is a multiport device that allow the interconnection of different power sources and enable them to cooperate to feed a load. The term is inspired in what is called a router in computer networks.

Figure 1 shows a general scheme of the use of an energy router for the interconnection of several power sources to a load. There is a block called policy energy subsystem that provides information about how much energy is convenient to be taken from each source. 
Such information depends on the total power being required by the load, environment conditions, the energy stored in energy storage devices, past records of use, energy production cost for each source, etc., . To build such block it is necessary to overcome some technological issues that are not addressed in this document. Instead it is assumed that the output of this subsystem is a vector $\alpha=\left[\alpha_{1}, \alpha_{2}, \ldots, \alpha_{n}\right]$. Where $\alpha_{i}$ value indicates the proportion of the total instantaneous power consumption that the $i_{t h}$ power source should provide. The energy router objective is to take the energy specified by $\alpha$ from each source to provide a regulated voltage to the load.

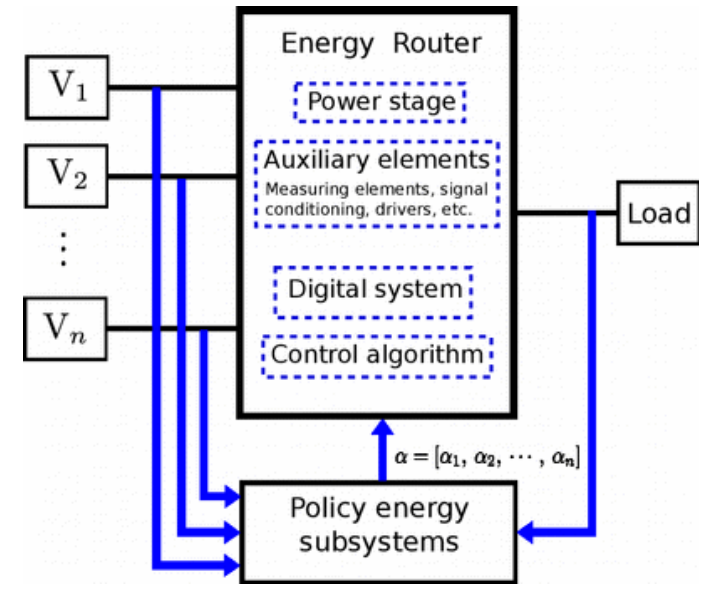

Figure 1. Cooperation of renewable source to feed a load

Let us call $P_{R}$ the total instantaneous power required by the load, $P_{i}$ the power taken form the $i_{\text {th }}$ power source, $V_{\text {ref }}$ the reference voltage and $V_{0}$ the actual output voltage. Hence the goals of an energy router are

1. Make the energy provided by each source equal to that specified by the energy policy subsystem. That is

$P_{i}=\alpha_{i} P_{R}$

where

$\alpha_{i} \in[0,1] ; \sum \alpha_{i}=1$

2. Provide a regulated reference voltage to the load

$$
V_{0} \rightarrow V_{\text {ref }}
$$

Note that, since the energy router is pretended to be used with renewable energy sources, input power source to an energy router can be of different dynamical characteristics (output voltage, output impedance, response time etc.).
Hence the energy router should be robust to load and input voltages variations.

In the following Sections it is shown that both the multi-input buck converter and the multiinput boost converter are able to function as an energy router if they are properly controlled.

\section{Enabling the Multi-Input Buck Inverter to Act as an Energy Router}

\subsection{Model of the multi-input buck converter}

In this section a multi-input buck converter is considered. To keep the notation simple only two sources are considered, however, is not difficult to extend the analysis to more sources. Figure 2 shows a simplified diagram of a multiinput buck converter for two sources. As it is shown in the Figure 2, $V_{1}$ and $V_{2}$ are the voltage of each power supply, $L_{1}$ and $L_{2}$ are the inductances, $C$ is the capacitance and $R$ is the load. The system state is composed of inductor currents $x_{1}, x_{2}$ and the output voltage $x_{3}$. A procedure to obtain a discontinuous model for this converter is to find out system equations for every possible configuration of the switches and then to combine all of them into a single model.

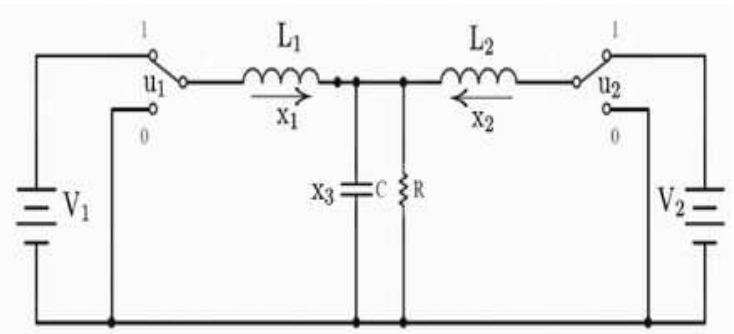

Figure 2. Multi-input buck converter

Considering $u_{1}=0$ and $u_{2}=0$ it is obtained

$L_{1} \dot{x}_{1}=-x_{3}$

$L_{2} \dot{x}_{2}=-x_{3}$

$C \dot{x}_{3}=x_{1}+x_{2}-\frac{x_{3}}{R}$

when $u_{1}=1$ and $u_{2}=1$, the model results

$L_{1} \dot{x}_{1}=V_{1}-x_{3}$

$L_{2} \dot{x}_{2}=V_{2}-x_{3}$

$C \dot{x}_{3}=x_{1}+x_{2}-\frac{x_{3}}{R}$

considering $u_{1}=0$ and $u_{2}=1$ it is obtained 


$$
\begin{aligned}
& L_{1} \dot{x}_{1}=-x_{3} \\
& L_{2} \dot{x}_{2}=V_{2}-x_{3} \\
& C \dot{x}_{3}=x_{1}+x_{2}-\frac{x_{3}}{R}
\end{aligned}
$$

finally considering $u_{1}=1$ and $u_{2}=0$ results

$$
\begin{aligned}
& L_{1} \dot{x}_{1}=V_{1}-x_{3} \\
& L_{2} \dot{x}_{2}=-x_{3} \\
& C \dot{x}_{3}=x_{1}+x_{2}-\frac{x_{3}}{R}
\end{aligned}
$$

Combining models (4-7) into a single one, it is obtained

$$
\begin{aligned}
& L_{1} \dot{x}_{1}=u_{1} V_{1}-x_{3} \\
& L_{2} \dot{x}_{2}=u_{2} V_{2}-x_{3} \\
& C \dot{x}_{3}=x_{1}+x_{2}-\frac{x_{3}}{R}
\end{aligned}
$$

It is important to point out that the model (8) is a discontinuous model because $u_{1,2} \in\{0,1\}$.

An average model can be derived from this one substituting the instantaneous states $x_{1}, x_{2}$ and $x_{3}$ by its averages $\tilde{x}_{1}, \tilde{x}_{2}$, and $\tilde{x}_{3}$ and the instantaneous switch positions $u_{1}$ and $u_{2}$ by its averages $\tilde{u}_{1}$ and $\tilde{u}_{2}$ (see $[2,20]$ for example). Usually power electronics specialist call $\widetilde{u}_{1}$ and $\widetilde{u}_{2}$ duty cycles and denotes them as $d_{1}$ and $d_{2}$ respectively.

\subsection{The multi-input buck converter is able to act as an energy router}

In this subsection it is shown that a properly controlled multi-input buck converter can achieve the requirements described in Section 2 for an energy router. For the multi-input buck converter shown in Figure 2 and modeled by (8) such requirements becomes

1. The power from source $V_{1}$ will provide a ratio $\alpha_{1}$ of the total power consumption, while source $V_{2}$ will provide a ratio $\alpha_{2}$. That is

$$
\begin{aligned}
& P_{V_{1}}=\alpha_{1} P_{R} \\
& P_{V_{2}}=\alpha_{2} P_{R}
\end{aligned}
$$

where $P_{V_{1}}$ and $P_{V_{2}}$ are the average power provided by the source 1 and the source 2 respectively. The condition (2) becomes $\alpha_{1,2} \in(0,1)$ with $\alpha_{1}+\alpha_{2}=1$.
2. The load voltage is regulated to a desired value

$$
x_{3} \rightarrow V_{r e f}
$$

Lema 1. Consider the multi-input buck converter shown in Figure 2 and modelled by (8). There exist a couple of values for $\widetilde{u}_{1}$ and $\tilde{u}_{2}$ that satisfy the requirements of an energy router, that is, satisfy (9) and (10).

Proof: From Figure 2 the power contributed by sources are

$$
\begin{aligned}
& P_{V_{1}}=\left(\widetilde{u}_{1} V_{1}\right) \widetilde{x}_{1} \\
& P_{V_{2}}=\left(\widetilde{u}_{2} V_{2}\right) \widetilde{x}_{2}
\end{aligned}
$$

and the total power delivered to the load is given by

$$
P_{R}=\frac{\tilde{u}_{3}^{2}}{R}
$$

Suppose that the initial conditions of (8) are such that

$$
\begin{aligned}
& x_{1}(0)=\alpha_{1} \frac{V_{r e f}}{R} \\
& x_{2}(0)=\alpha_{2} \frac{V_{r e f}}{R} \\
& x_{3}(0)=V_{r e f}
\end{aligned}
$$

If average of $u_{1}$ and $u_{2}$ are set to

$\tilde{u}_{1}=\frac{\tilde{x}_{3}}{V_{1}}$

$\tilde{u}_{2}=\frac{\widetilde{x}_{3}}{V_{2}}$

then $\dot{\tilde{x}}_{1}=\dot{\tilde{x}}_{2}=\dot{\tilde{x}}_{3}=0$. Hence, the system is in equilibrium. Rewriting (14a) and (14b) as

$$
\begin{aligned}
& \tilde{u}_{1} V_{1}=\tilde{x}_{3} \\
& \tilde{u}_{2} V_{2}=\tilde{x}_{3}
\end{aligned}
$$

Multiplying (15a) by $\tilde{x}_{1}$ and (15b) by $\tilde{x}_{2}$ it is obtained

$$
\begin{aligned}
& \left(\tilde{u}_{1} V_{1}\right) \tilde{x}_{1}=\tilde{x}_{1} \tilde{x}_{3} \\
& \left(\tilde{u}_{2} V_{2}\right) \tilde{x}_{2}=\tilde{x}_{2} \tilde{x}_{3}
\end{aligned}
$$

Taking into account (11) in (16) results

$$
\begin{aligned}
& P_{V_{1}}=\tilde{x}_{1} \tilde{x}_{3} \\
& P_{V_{2}}=\tilde{x}_{2} \tilde{x}_{3}
\end{aligned}
$$

Since the control and initial conditions are such that the system is in equilibrium then we can substitute (13) in (17) to get 


$$
\begin{aligned}
& P_{V_{1}}=\alpha_{1} \frac{V_{r e f}^{2}}{R} \\
& P_{V_{2}}=\alpha_{2} \frac{V_{r e f}^{2}}{R}
\end{aligned}
$$

Hence, from (12) follows that given the initial conditions (13) and the control (14) the system remain in equilibrium and in this equilibrium $P_{V_{1}}=\alpha_{1} P_{r}$ and $P_{V_{2}}=\alpha_{2} P_{r}$.

Remark 2. It is important to point out that from lemma 1, particularly from (13) in steady state, the equations

$$
\begin{aligned}
& x_{1 s s}=\alpha_{1} \frac{V_{r e f}}{R} \\
& x_{2 s s}=\alpha_{2} \frac{V_{r e f}}{R} \\
& x_{3 s s}=V_{r e f} \\
& \tilde{x}_{1 s s}+\tilde{x}_{2 s s}=\left(\alpha_{1}+\alpha_{2}\right) \frac{V_{r e f}}{R}=\frac{V_{r e f}}{R}
\end{aligned}
$$

must hold.

\subsection{Control of the multi-input buck converter to function as an energy router}

In Subsection 3.2 has been shown that the multi-input buck converter is able to function as an energy router in the sense that if the system starts with a particular initial conditions there exist an open-loop controller that accomplishes the energy router goals. However in practice we can not rely neither in special initial condition nor in open-loop controller. Hence a closed loop controller is necessary.

It has been shown from some decades now that in general, control of power converters is easier if the voltage is indirectly controlled through the current (see for example $[10,11]$ ). Based on this observation the following switching laws are proposed

$$
u_{i}=\left\{\begin{array}{lll}
1 & \text { si } & \tilde{x}_{i}-x_{\text {iref }}<0 \\
0 & \text { si } & \tilde{x}_{i}-x_{\text {iref }}>0
\end{array} \quad ; \quad i=\{1,2\}\right.
$$

where $\tilde{x}_{1_{n f}}$ and $\tilde{x}_{2_{n f}}$ are expressions that must depend on the output voltage in order to achieve a desired output voltage. In what follows these references are obtained.

To accomplish the goal given by (10) let suppose for a moment that

$$
v=x_{1}+x_{2}
$$

is a fictitious control in (8c). In this way, (8c) becomes the first order linear system

$\dot{x}_{3}=a x_{3}+b v$

where $a=\frac{-1}{R C}$ and $b=\frac{1}{C}$ It is well known (see [8]) that system (22) can be compensated by (23)

$$
v=k_{p}\left(V_{\text {ref }}-x_{3}\right)+k_{\text {int }} \int_{0}^{t}\left(V_{r e f}-x_{3}\right) d \tau
$$

that is, a classic PI controller where the gains $k_{p}$ and $k_{i}$ are adjusted based on linear control techniques. From (21) and (23) the sum of the desirable current references can be obtained

$$
\begin{aligned}
x_{1 \text { ref }}+x_{2 \text { ref }} & =k_{p}\left(V_{\text {ref }}-x_{3}\right) \\
& +k_{\text {int }} \int_{0}^{t}\left(V_{\text {ref }}-x_{3}\right) d \tau
\end{aligned}
$$

From (21), (22) and (23) it can be concluded that if

$$
x_{1}+x_{2} \rightarrow x_{1 \text { ref }}+x_{2 \text { ref }}
$$

where $x_{1 \text { ref }}+x_{2 \text { ref }}$ is given by (24) then the goal given by (10) is achieved. Nevertheless, the goals given by (9) can not yet be guaranteed. However, note that for the goals (9) to be achieved then in steady state conditions (19) must hold. Hence in steady state equations

$$
\begin{aligned}
& x_{1 s s}=\alpha_{1}\left(x_{1 \text { ref }}+x_{2 r e f}\right) \\
& x_{2 s s}=\alpha_{2}\left(x_{1 \text { ref }}+x_{2 r e f}\right)
\end{aligned}
$$

must hold. From (24) and (26) it can be concluded that for the goals (9) to be achieved, conditions (27) must hold.

$$
\begin{aligned}
x_{1} \rightarrow x_{1 r e f} & =\alpha_{1}\left[k_{p}\left(V_{r e f}-x_{3}\right)\right. \\
& \left.+k_{\text {int }} \int_{0}^{t}\left(V_{r e f}-x_{3}\right) d \tau\right] \\
x_{2} \rightarrow x_{2 r e f} & =\alpha_{2}\left[k_{p}\left(V_{r e f}-x_{3}\right)\right. \\
& \left.+k_{\text {int }} \int_{0}^{t}\left(V_{r e f}-x_{3}\right) d \tau\right]
\end{aligned}
$$

To conclude this subsection, it should be noted that control algorithm given by (20) and (27) can also be expressed using the standard notation for sliding mode controllers:

$u_{i}=\left\{\begin{array}{lll}1 & \text { si } & \sigma_{i}(x)<0 \\ 0 & \text { si } & \sigma_{i}(x)>0\end{array}\right.$

with (29).

$$
\begin{aligned}
\sigma_{i}(x) & =x_{i}+\alpha_{i}\left(k_{p}\left(x_{3}-V_{r e f}\right)\right. \\
& \left.+k_{\text {int }} \int_{0}^{t}\left(x_{3}-V_{r e f}\right) d \tau\right)
\end{aligned}
$$




\subsection{Simulation results}

To evaluate the controller performance, in this Section a multi-input buck converter with the parameters shown in Table 1 is simulated.

Table 1. Multi-input buck converter parameters

\begin{tabular}{c|c}
\hline$V_{o}$ & $12 V_{C D}$ \\
\hline$L_{1}$ & $360 \mu \mathrm{H}$ \\
\hline$L_{2}$ & $240 \mu \mathrm{H}$ \\
\hline$C$ & $62.5 \mu \mathrm{F}$ \\
\hline$R$ & $3 \Omega$ \\
\hline$V_{1}$ & $48 V_{C D}$ \\
\hline$V_{2}$ & $24 V_{C D}$ \\
\hline$\alpha_{1}$ & 0.4 \\
\hline$\alpha_{2}$ & 0.6
\end{tabular}

Figures 3, 4, and 5 show simulation results under different test condition. Figure 3 shows the output and input voltages, in Figure 4 partials and total currents are shown. In Figure 5 the power contribution of each source and the total power consumption are shown. The test conditions to be simulated are startup, change on $\alpha_{1}, \alpha_{2}$ and changes on load a source voltage values.

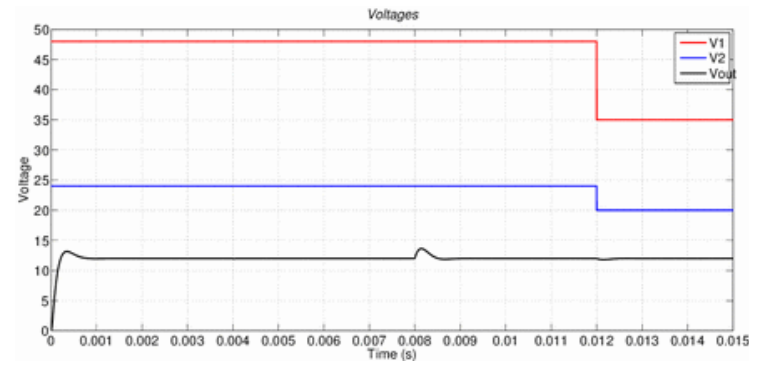

Figure 3. Source voltages.

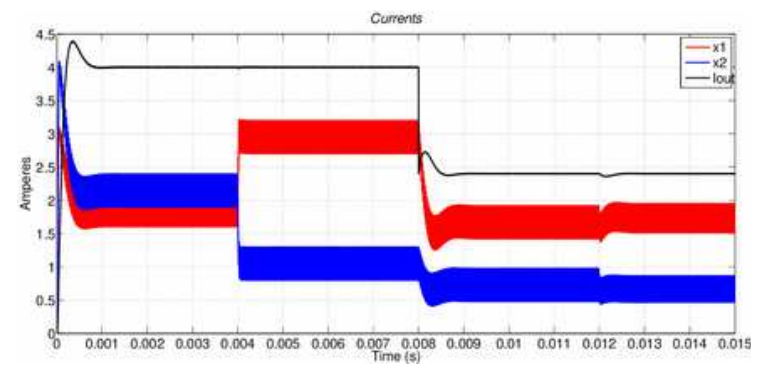

Figure 4. Inductor currents

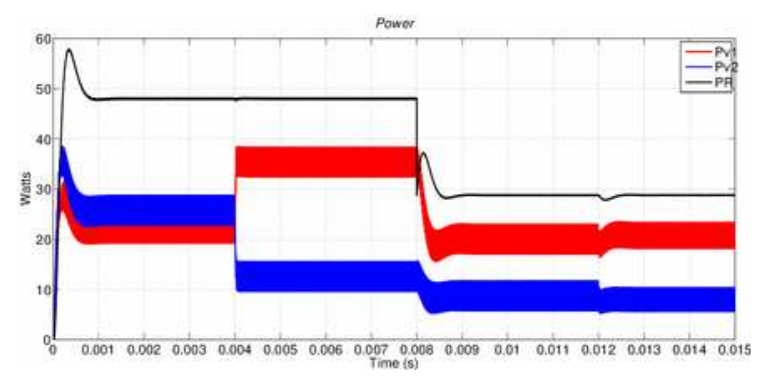

Figure 5. Source power
Note that start-up is fast, with a settling time of about $800 \mu \mathrm{S}$. To illustrate what would happen if for example a source is not able to provide the $60 \%$ of power, at $4 \mathrm{mS}$ the parameter $\alpha_{2}$ is changed from 0.6 to 0.2 . Note that almost instantaneously the current and hence the power that each source provides change. There is an almost neglect-able perturbation in the output voltage. At $8 \mathrm{mS}$ the load is changed from $3 \Omega$ to $5 \Omega$. Note there is a fast recovering of the output voltage. Power consumption changes as the load change, hence the power that each source provides also changes. However, the proportion of the total power that each source provides remain the same. Finally to illustrate the control robustness under voltage variations, at $12 \mathrm{mS}$ both power source voltages are changed.

The first perturbation consisted in modifying the power provided by every source modifying the initial parameters after $4 \mathrm{~ms}$. It is also changed the load value from $3 \Omega$ to $5 \Omega$, to $8 \mathrm{~ms}$. In Figure 3 the voltages are presented, where is possible to observe that the source voltages $\left(V_{1}, V_{2}\right)$ are superior to the desired voltage $\left(V_{\text {out }}\right)$, showing that the change in the provided power from the sources does not interferes importantly with the voltage, while the load perturbation does present a 5 volt perturbation which is corrected. In Figure 4 is observed that the addition of the inductors current $\left(x_{1}, x_{2}\right)$ is the current used by the load $\left(i_{\text {out }}\right)$, in the same way the change in power which every source provides is appreciated. In Figure 5, is presented the behavior of the power of the sources $\left(P_{V_{1}}, P_{V_{2}}\right)$ in respect of the load power $\left(P_{R}\right)$, showing that they maintain proportional to the control adjustment.

\section{Enabling Multi-input Boost Converter to Act as an Energy Router}

Like the multi-input buck converter, a multiinput boost converter is generated by connecting two boost converters as it is shown in Figure 6. Multi-input boost converters have been previously used in hybrid systems with alternate energies [6, 14]. However these works do not address the problem of feeding a load cooperatively with two or more sources. Along similar lines used for the multi-input buck converter, in this Section a control for the 
multi-input boost converter, that enable it to act as an energy router is developed.

\subsection{Model of the multi-input boost converter}

The model for the topology of Figure 6 can be obtained combining the state equations for every position of switches $u_{1}$ and $u_{2}$, like was done for the multi-input buck converter. The resulting model is

$$
\begin{aligned}
& L_{1} \dot{x}_{1}=V_{1}-u_{1} x_{3} \\
& L_{2} \dot{x}_{2}=V_{2}-u_{2} x_{3} \\
& C \dot{x}_{3}=u_{1} x_{1}+u_{2} x_{2}-\frac{x_{3}}{R}
\end{aligned}
$$

where $V_{1}, V_{2}$ are the source voltages, $x_{1}$ and $x_{2}$ are the inductor currents, $x_{3}$ is the capacitor voltage, $L_{1}$ and $L_{2}$ are the inductances, $C$ is the capacitance and $R$ is the load. Note that $u_{1,2} \in\{0,1\}$.

\subsection{The multi-input boost converter is able to act as an energy router}

In this subsection it is shown that a multi-input boost converter is able to performs the functions of an energy router if it is properly controlled.

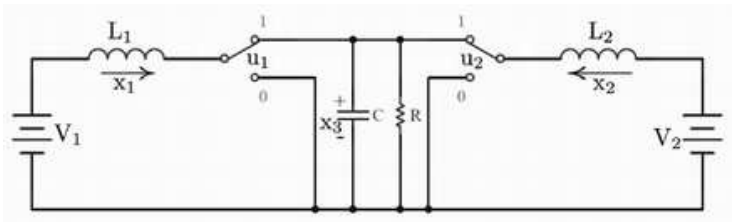

Figure 6. Multi-input boost converter

For the multi-input boost converter shown in Figure 6 and modeled by (30) the requirements specified in Section 2 for an energy router become

1. The power from source $V_{i}$ will provide a ratio $\alpha_{i}$ of the total power consumption, That is

$$
\begin{aligned}
& P_{V_{1}}=\alpha_{1} P_{R} \\
& P_{V_{2}}=\alpha_{2} P_{R}
\end{aligned}
$$

where $P_{V_{1}}$ and $P_{V_{2}}$ are the average power provided by the source 1 and the source 2 respectively. The condition (2) becomes $\alpha_{1,2} \in[0,1]$ with $\alpha_{1}+\alpha_{2}=1$.

2. The load voltage is regulated to a desired value

$$
x_{3} \rightarrow V_{r e f}
$$

Lemma 3. Consider the topology shown in Figure 6 modeled by (30). There are a couple of values $\tilde{u}_{1}$ and $\tilde{\widetilde{u}}_{2}$ such that the requirements (31) and (32) are accomplished.

Proof: The contributed power of each source can be obtained from the Figure 6, resulting

$$
\begin{aligned}
& P_{V_{1}}=V_{1} \tilde{x}_{1} \\
& P_{V_{2}}=V_{2} \tilde{x}_{2}
\end{aligned}
$$

The total power delivered to the load is given by

$$
P_{R}=\frac{\tilde{x}_{3}^{2}}{R}
$$

Lets suppose that the initial conditions of (30) are given by

$$
\begin{aligned}
& x_{1}(0)=\alpha_{1} \frac{V_{r e f}^{2}}{R V_{1}} \\
& x_{2}(0)=\alpha_{2} \frac{V_{r e f}^{2}}{R V_{2}} \\
& x_{3}(0)=V_{r e f}
\end{aligned}
$$

and that average controls are given by

$$
\begin{aligned}
& u_{1}=\frac{V_{1}}{V_{\text {ref }}} \\
& u_{2}=\frac{V_{2}}{V_{\text {ref }}}
\end{aligned}
$$

Substituting the initial conditions (35) and the control expressions (36) in the model (30) it is obtained that under such conditions $\dot{x}_{1}=\dot{x}_{2}=\dot{x}_{3}=0$. That is the system is in equilibrium. Hence in this state

$$
\begin{aligned}
& x_{1}(t)=\alpha_{1} \frac{V_{r e f}^{2}}{R V_{1}} \\
& x_{2}(t)=\alpha_{2} \frac{V_{r e f}^{2}}{R V_{2}} \\
& x_{3}(t)=V_{r e f} \\
& P_{R}=\frac{V_{r e f}^{2}}{R}
\end{aligned}
$$

Substituting (37a) in (33a) results

$$
P_{V_{1}}=V_{1} \alpha_{1} \frac{V_{r e f}^{2}}{R V_{1}}=\alpha_{1} \frac{V_{r e f}^{2}}{R}
$$

from (37d) it is concluded that the requirement (31a) is achieved. Similarly from (31b) and using (37d) it is concluded that the requirement $(31 \mathrm{~b})$ is achieved. 
This shows that topology of Figure 6 is able to function as an energy router in the sense that there exist initial conditions and open loop controllers that achieved goals (31) and (32). However, this is an ideal case which does not have practical sense. In the next Section a closed loop controller is presented.

\subsection{Control of the multi-input boost converter to function as an energy router}

It is known that the indirect control of the output voltage through the inductor current presented for the buck converter in section also works for the boost converter. Based on this fact, it is possible to develop a control algorithm for the multi-input boost along very similar lines used for the multi-input buck. The resulting algorithm has the same form given by (20) and (27) or expressed as (2829). Note that, although the control algorithm has the same form for the multi-input buck and for the multi-input boost the components values are usually different for the two topologies and constant $k_{p}$ and $k_{i}$ as well.

\subsection{Simulation results}

In this Section simulation results of a multiinput boost converter working as an energy router will be presented. The parameters used are shown in Table 2. Figures 8 , and 9 show the results. Figure 7 shows the output and input voltages, in Figure 8 partials and total currents are shown. In Figure 9 the power contribution of each source and the total power consumption are shown. Simulation was carried out in a similar way that in Subsection 3.4.

Table 2. Multi-input boost converter parameters

\begin{tabular}{c|c}
\hline$V_{o}$ & $50 V_{C D}$ \\
\hline$L_{1}$ & $250 \mu \mathrm{H}$ \\
\hline$L_{2}$ & $300 \mu \mathrm{H}$ \\
\hline$C$ & $30 \mu \mathrm{F}$ \\
\hline$R$ & $15 \Omega$ \\
\hline$V_{1}$ & $24 V_{C D}$ \\
\hline$V_{2}$ & $20 V_{C D}$ \\
\hline$\alpha_{1}$ & 0.4 \\
\hline$\alpha_{2}$ & 0.6 \\
\hline
\end{tabular}

After the start-up, at $4 \mathrm{mS}$ the power provided by the sources is redefined by modifying $\alpha_{1}=0.8$ and $\alpha_{2}=0.2$. To show the controller robustness under load changes, at 8 $m S$ the load is changed from $15 \Omega$ to $10 \Omega$. Finally, to illustrate the robustness under input voltage variations, at $12 \mathrm{~ms}$ both source voltages are changed. It can be observed that through all these perturbations the output voltage has a fast recovery.

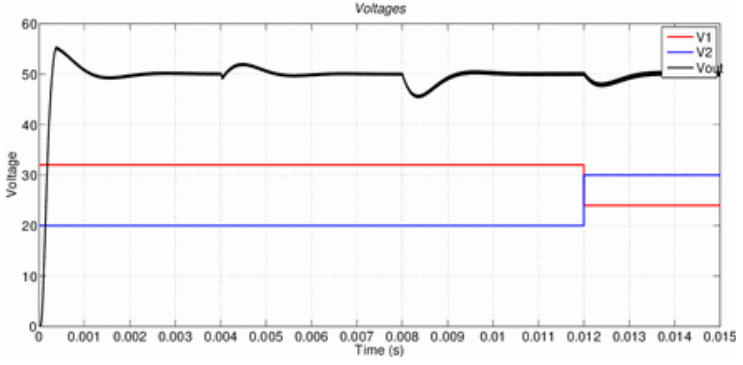

Figure 7. Voltages

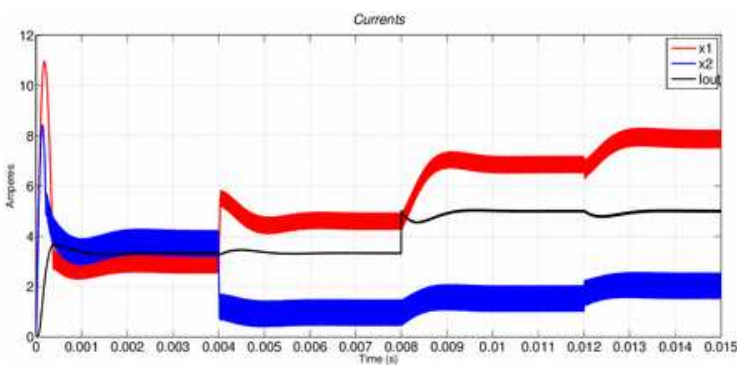

Figure 8. Currents

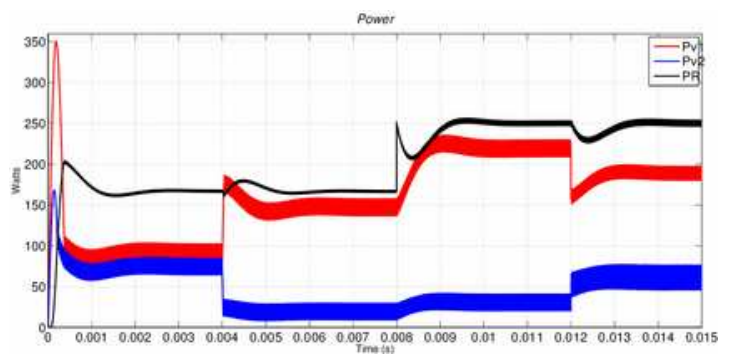

Figure 9. Power

\section{Conclusions}

As the use of renewable energy grows, there is going to be necessary to interconnect them efficiently. An energy router is a device to perform this interconnection. In this paper has been shown that the multi-input buck and multi-input boost converters are able to perform the functions of an energy router. A control algorithm has been developed for enabling these converter to function as an energy router.

Simulation results show that the controlled multi-input converters are able to interconnect to different sources to feed the load with a regulated voltage and at the same time allow to decide how much energy each source should provide.

The controller can be seen as an extension of the current-mode control for the single input buck and boos converters. Although two 
sources has been considered in this paper, it is not difficult to extend the results for more than two sources.

\section{Acknowledgments}

This research has been partially supported by Mexico City Secretaria of Science, Technology and Innovation under grant ICYTDF-198-2012.

\section{REFERENCES}

1. DOBBS, B. G., P. L. CHAPMAN, A Multiple-Input DC-DC Converter Topology. Power Electronics Letters, IEEE, vol.1, iss. 1.

2. CORTES, D. Generación de Voltajes de Corriente Alterna Mediante Convertidores de Alta Frecuencia de Conmutación. $\mathrm{PhD}$ thesis, Centro de Investigación Cientifica y Estudios Superiores de Ensenada, 2004.

3. SOTO, J. B. D., Control of a Modular Multilevel Matrix Converter for High Power Applications. Studies in Informatics and Control, ISSN 1220-1766, vol. 21(1), 2012, pp. 85- 92.

4. DING, A., G. KWASINSKI, Digital Constant On-time Controlled Multipleinput Buck and Buck-Boost Converters. In Applied Power Electronics Conference and Exposition (APEC), 2013 TwentyEighth Annual IEEE, pp. 1376, 1382. 17 March 2012.

5. GHANBARI FARJAH, S., E. REZAEE, Sliding Mode Control of a Novel Multiinput Split-inductor Buck-boost Converter, 25th IEEE Canadian Conference on Electrical \& Computer Engineering (CCECE), 2012, pp. 1, 4.

6. DANYALI HOSSEINI, S. K., S. H. HAGHIGHIAN, Multi-input DC Boost Converter Supplied by a Hybrid PV/Wind Turbine Power Systems for Street Lighting Application Connected to the Grid. In 47th International Universities Power Engineering Conference (UPEC), 2012, pp. 1, 6.

7. HARTESCU, F., I. MICIU, Monitoring System for Cogenerative Power Plants. Studies in Informatics and Control, vol. 18(4), 2009, pp. 379-388.
8. K. OGATA, Modern Control Engineering. Prentice Hall, USA, 3rd edition, 1997.

9. TAMER, K. S. K., A. MOHAMED, Optimal Sizing of Building Integrated Hybrid PV/diesel Generator System for Zero Load Rejection for Malaysia, Energy and Buildings. ELSEVIER, vol. 43, no. 12 , pp. 3430-3435.

10. LIU, P. C., Y.-F. SEN, A General Unified Large Signal Model for Current Programmed DC-To-DC Converters, IEEE Transactions on Power Electronics, vol. 9 , is. 4 .

11. MIDDLEBROOK, R. D. Modeling Current-programmed Buck and Boost Regulators. IEEE transactions on Power Electronics.

12. ESCOBAR, B., O. BELTRÁN, R. BARBOSA, Análisis y propuesta de un protocolo para la gestión de la energía de un sistema híbrido Eólico-SolarHidrógeno. In Conr. int. ing. electrón. mem. Eléctro, vol. 33, pp. 222-227 Chihuahua, Chih. México. 2011.

13. OECD. OECD Environmental Outlook to 2050: The Consequences of Inaction. OECD Publishing, 2012.

14. NEJABATKHAH OSSEINI, S.; S. H. DANYALI, Multi-input DC Boost Converter for Grid Connected Hybrid PV/FC/Battery Power System. In Electric Power and Energy Conference (EPEC), 2010 IEEE., August 2010, pp. 1, 6, 25-27.

15. MENDOZA, F., R. DUFO LOPEZ, J. L. BERNAL AGUSTÍN, Diseño y análisis económico de los sistemas PV-viento híbridos conectados a la red para la producción intermitente de hidrógeno. Energy policy, vol. 37, no. 8, August 2009, p. 3082 .

16. LEFEBVRE, D., S. ZERKAOUI, A. B. MBOOUP, Sliding Mode based Control Strategy for Multisources Renewable Energy System. In International Conference on Electric Power and Energy Conversion Systems, 2009. EPECS '09, 10 November 2009, pp. 1, 6.

17. SÁNCHEZ-SQUELLA, R. G., A. ORTEGA, Dynamic Energy Router. Control Systems, IEEE, vol. 30, no. 6, December 2010, pp. 72, 80. 
18. CHOUNG, S. H., A, KWASINSKI, Multiple-input DCDC Converter Topologies Comparison. In IEEE of 34th Annual Conference on Industrial Electronics, 2008. IECON 2008.

19. TIAN, Y., S. LI, H. WANG, NNPID-based Stator Voltage Oriented Vector Control for DFIG based Wind Turbine Systems. Studies in Informatics and Control, vol. 23(1), 2014, pp. 5-12.

20. UTKIN, V., Sliding Modes in Control and Optimization. Communications and Control Egineering. Springer Verlag. 1991.

21. CHIU, H.-J., H.-M. HUANG, L.-W. LIN, M.-H. TSENG, A Multiple-Input DC/DC Converter for Renewable Energy Systems Industrial Technology, IEEE International Conference on ICIT 2005. Dec. 2005.

22. RAMIREZ, V., R. ORTEGA, R. GRINO, A. SANCHEZ-SQUELLA, O. BETHOUX, Theory and Experimental Results of Two Dynamic Energy Routers. American Control Conference (ACC), 2012
23. .ZERKAOUI, S. A. B. MBOUP, D. LEFEBVRE, F. GUERIN, J. BOSCHE, E. HAJJAJI, A Sliding Mode Based Control Strategy for Multi-sources Renewable Energy System Electric Power and Energy Conversion Systems. International Conference on EPECS '09, 2009.

24. WEI, J., B. FAHIMI, Multiport Power Electronic Interface-Concept, Modeling, and Design Power Electronics, IEEE Trans., vol. 26, is. 7, 2011, pp. 1890-1900.

25. Di NAPOLI, A., F. CRESCIMBINI, S. RODO, L. SOLERO, Multiple Input DCDC Power Converter for Fuel-cell Powered Hybrid Vehicles Power Electronics Specialists Conference, 2002. PESC 02. 2002 IEEE 33rd Annual vol. 4, 2002, pp. 1685-1690.

26. SOLERO, L., A. LIDOZZI, J. A. POMILIO, Design of Multiple-input Power Converter for Hybrid Vehicles IEEE Transactions on Power Electronics, vol. 20 , is. 5,2005 , pp. 1007-1016. 